\title{
Medical Students' Perceptions of Pathology and a Proposed Curricular Integration with Histology: A Future Vision of Curricular Change
}

\author{
Percepciones de los Estudiantes de Medicina sobre Patología y una Propuesta de \\ Integración Curricular con Histología: Una Visión Futura de Cambio Curricular
}

Ali Al Khader ${ }^{1}$; Fatima N. Obeidat ${ }^{2}$; Nisreen Abu Shahin ${ }^{2}$; Nabil A. Khouri ${ }^{3}$; Ezidin G. Kaddumi ${ }^{1}$; Shifaa' Al Qa'qa' ${ }^{1}$; Tariq N. Al-Shatanawi ${ }^{1}$; Hatem Jaber ${ }^{1}$; Mohamad Al-Saghbini ${ }^{1}$ \& Nabil Amer ${ }^{1}$

AL KHADER, A.; OBEIDAT, F. N.; ABU SHAHIN, N.; KHOURI, N. A.; KADDUMI, E. G.; AL QA'QA', S.; AL-SHATANAWI, T. N.; JABER, H.; AL-SAGHBINI, M. \& AMER, N. Medical students' perceptions of pathology and a proposed curricular integration with histology: A future vision of curricular change. Int. J. Morphol., 38(1):38-42, 2020.

SUMMARY: Students' perceptions and feedback have a significant impact on academic progress. The aim of this study was to determine the perceptions of medical students regarding the cumulative effects of the first year general histology course and the sophomore pathology introductory course, in addition to their perceptions regarding the curricular integration of histology and pathology. In this cross-sectional study, a questionnaire was given to second-year and third-year medical students in the middle of second semester. The questionnaire comprised several items on students' attitudes toward anatomic pathology, their feedback on the first year general histology and the sophomore pathology courses, and their perceptions regarding the integration of histology and pathology courses. A five-point Likert scale was used. Data were analyzed using Statistical Package for the Social Science (SPSS) v 20 software. Two hundreds and fourteen of the 236 questionnaires distributed were analyzed (response rate $=90.7 \%$ ). More than $51 \%$ of the respondents reported that they couldn't identify the normal tissue counterpart of most practical pathology cases. Only $31.3 \%$ thought their practical histology knowledge was beneficial for them in practical pathology. More than $87 \%$ agreed or strongly agreed that pathology cases need to be copresented with normal tissue examples. A significant proportion of the respondents $(60.7 \%)$ were with merging histology and pathology in integrated courses. Pathology was of career choices for only $15.4 \%$ of the participants. The curricular integration of histology and pathology in the first year needs to be tested, and much effort is needed to increase students' affinity for anatomic pathology.

KEY WORDS: Pathology; Histology; Medical students.

\section{INTRODUCTION}

Teaching pathology as an image intensive discipline is of the major challenges medical teachers are faced with. This fact also applies to histology teaching in which much effort has been made to boost students' knowledge retention. Both "traditional" and "nontraditional" methods have been used (Hightower et al., 1999), and modalities such as peer teaching (Beck et al., 2016), audiovisual tools (CamposSánchez et al., 2014) and technological and traditional drawing approaches (Cogdell et al., 2012; Rafi et al., 2017) have been extensively studied and tested. In addition, virtual microscopy proved to be beneficial in many aspects (Herrmann et al., 2015; Hortsch, 2017). Understanding of histology is essential for every medical student when doing pathology at medical school. Moreover, integration of histology into clinical context was tested and it proved to be successful (Singh, 2011; Shaw \& Friedman, 2012; MalauAduli et al., 2013). However, more effort is needed to change students' attitudes toward the clinical importance of histology (Moxham et al., 2017). From pathology point of view, many integrated curricula have been tested and used in an attempt to reach maximal students' retention of the pathology knowledge they need in their clinical practice (Haspel et al., 2012; Malau-Aduli et al.; Atukorala \& Atapattu, 2015; Lisk et al., 2016). However, little is known about the actual difficulties the students face when they try to identify morphologic changes in diseased tissues, and these difficulties need to be systematically addressed. Challenges in achieving competencies in practical histopathology may

\footnotetext{
${ }^{1}$ Department of Basic Medical Sciences, Faculty of Medicine, Al-Balqa applied University, Al-Salt, Jordan.

${ }^{2}$ Department of Pathology and Microbiology and Forensic Medicine, Faculty of Medicine, University of Jordan, Amman, Jordan.

${ }^{3}$ Department of anatomy, Jordan University of science and technology, Irbid, Jordan.
} 
AL KHADER, A.; OBEIDAT, F. N.; ABU SHAHIN, N.; KHOURI, N. A.; KADDUMI, E. G.; AL QA'QA', S.; AL-SHATANAWI, T. N.; JABER, H.; AL-SAGHBINI, M. \& AMER, N. Medical students' perceptions of pathology and a proposed curricular integration with histology: A future vision of curricular change. Int. J. Morphol., 38(1):38-42, 2020.

contribute to medical students' attitudes toward anatomic pathology as a career choice in spite of their awareness of its importance in medicine. Medical students' perceptions of pathology as a career choice has been debated worldwide (Holland \& Bosch, 2006; Hung et al., 2011; Ghanchi et al., 2017), and this debate has been linked to population-based consequences. In a study from Canada, for example, the average case load of cancer for pathologists has shown significant increase during the period 1999-2009, and this shortage lead to the conclusion that monitoring the quality of pathology practice is needed (Colgan \& Geldenhuys, 2012). From medical students' perspective, keeping pathology invisible for the graduating medical students makes them ignore pathology and reject pathology residency. This necessitates integrating pathology in the clinical clerkships to better perceive the importance of pathology in clinical practice and the positives of being pathologist (Hung et al.). Taking into consideration that students' perceptions and feedback have a significant impact on academic progress, our study aims to determine the perceptions of medical students regarding normal and abnormal microscopic morphology and their feedback regarding cumulative effects of the first year general histology course and the sophomore pathology introductory course. In addition, our study emphasizes on students' perceptions regarding integrating histology and pathology as a future vision of curricular change, especially if this integration starts in the first year. This integration may boost the knowledge retention in histopathology, which may aid in a better view of pathology relative to other specialties and increase the perceived positives of pathology as a career choice.

\section{MATERIAL AND METHOD}

This cross-sectional study was conducted at the faculty of medicine, Al-Balqa applied university which is a public university in central Jordan. After obtaining the ethical approval, an anonymous predesigned self-administered questionnaire was given to second-year and third-year medical students in the second semester of the academic year 2017/2018 with more than 200 surveys collected. Informed consent was obtained verbally. The survey comprised questions on students' affinity for anatomic pathology, the difficulties that they faced in examining histopathology slides, their assessment of practical histology knowledge retention and their perceptions regarding the integration of histology and pathology in integrated courses. A five-point Likert scale was used. Data were analyzed using SPSS v 20 software. Descriptive statistics and Pearson's chisquared test were used, and $\mathrm{P}<0.05$ was considered significant.

\section{RESULTS}

A total of 236 questionnaires were distributed, and 214 students participated in the study (response rate $=90.7$ $\%)$. There were $93(43 \%)$ males and 121 (57\%) females, with a male-to-female (M:F) ratio of $0.77: 1$. The mean age of the participants was 20.12 years $(\mathrm{SD}=0.86)$. Of them, $121(57 \%)$ were from the second year, and $93(43 \%)$ were from the third year. Out of the 214 respondents, $156(72.9$ $\%)$ found pathology interesting. Moreover, 188 (87.9\%) perceived the importance of pathology in medicine. However, only $33(15.4 \%)$ thought of pathology as a career choice. When compared to other disciplines, only 73 (34.1 $\%), 53(24.8 \%)$ and $43(20.1 \%)$ of the participants felt pathology was easier than anatomy, physiology, and biochemistry, respectively. In regard to practical pathology, $94(44.0 \%)$ of the participants found pathology lab sessions interesting. However, $107(50.0 \%)$ students found morphology of disease more difficult than other aspects of pathology, and $159(74.3 \%)$ students found microscopic morphology of disease more difficult than gross morphology. Of the participants, only $63(29.4 \%)$ reported that their grades in practical pathology exams were higher than theoretical exams (Table I).

Regarding the knowledge retention of histology, only $67(31.3 \%)$ students responded that they remembered normal microscopic morphology well when they tried to identify microscopic disease morphology in the introductory pathology course. One hundred and ten $(51.4 \%)$ students reported that they couldn't identify the normal tissue counterpart in more than half of the practical pathology cases in the introductory course. A significant proportion of the participants $187(87.4 \%)$ agreed or strongly agreed that supporting pathology microscopic examples by normal tissue counterparts was needed. In addition, 94 (44.0\%) found histology lab sessions of the first year histology course interesting (Table II).

There were $129(60.3 \%)$ students that felt unsatisfied with the practical sessions of the first year histology course. On the other hand, 103 (48.1\%) of the participants felt unsatisfied with the number of pathology lab sessions in the second year pathology course. One hundred and thirty (60.7 $\%$ ) preferred the integration of histology and pathology lectures and lab sessions in integrated courses starting from the first year instead of separating the first year histology course from the second year pathology introductory course. Moreover, adding case discussions integrating histology and pathology in the first and second years was preferred by $148(69.2 \%)$ of the participants. In addition, $151(70.6 \%)$ responded that system approach in general is better than 
Table I. Participants' perceptions of pathology and the second year pathology introductory course.

\begin{tabular}{lccc}
\hline Questionnaire element & $\begin{array}{c}\text { Strongly } \\
\text { disagre e/Disagree (\%) }\end{array}$ & $\begin{array}{c}\text { Neutral } \\
(\%)\end{array}$ & $\begin{array}{c}\text { Strongly } \\
\text { Agree/Agree (\%) }\end{array}$ \\
\hline Pathology is important in medicine. & $5(2.3)$ & $21(9.8)$ & $188(87.9)$ \\
Pathology was interesting to learn. & $8(3.7)$ & $50(23.4)$ & $156(72.9)$ \\
Pathology is of your career choices in the future. & $120(56.1)$ & $61(28.5)$ & $33(15.4)$ \\
Pathology lab sessions were interesting. & $32(15.0)$ & $71(33.2)$ & $111(51.8)$ \\
Practical pathology was more difficult than theory. & $49(22.9)$ & $58(27.1)$ & $107(50.0)$ \\
Microscopic morphology of disease was more difficult to identify & $15(7.0)$ & $40(18.7)$ & $159(74.3)$ \\
than gross morphology. & $63(29.4)$ & $72(33.6)$ & $79(37.0)$ \\
Your marks in practical pathology exams we re worse than theory. & $73(34.1)$ & $39(18.2)$ & $102(47.7)$ \\
Pathology was more difficult than anatomy. & $53(24.8)$ & $70(32.7)$ & $91(42.5)$ \\
Pathology was more difficult than physiology. & $43(20.1)$ & $41(19.2)$ & $130(60.7)$ \\
Pathology was more difficult than biochemistry. & $115(53.7)$ & $55(25.7)$ & $44(20.6)$ \\
Pathology was more difficult than microbiology. & $94(43.9)$ & $24(11.2)$ & $96(44.9)$ \\
Pathology was more difficult than community medicine. & $81(37.9)$ & $67(31.3)$ & $66(30.8)$ \\
Pathology was more difficult than pharmacology. & $54(25.2)$ & $57(26.7)$ & $103(48.1)$ \\
Practical pathology needs more lab sessions and more effort by & & & \\
instructors than what you took. & & & \\
\hline
\end{tabular}

Table II. Participants' perceptions and feedback on the first year histology course.

\begin{tabular}{lccc}
\hline Questionnaire element & $\begin{array}{c}\text { Strongly } \\
\text { disagree/Disagree (\%) }\end{array}$ & $\begin{array}{c}\text { Neutral } \\
(\%)\end{array}$ & $\begin{array}{c}\text { Strongly } \\
\text { Agree/Agree (\%) }\end{array}$ \\
\hline $\begin{array}{l}\text { Histology lab sessions were interesting. } \\
\text { Practical histology was more difficult than theory. }\end{array}$ & $60(28.0)$ & $60(28.0)$ & $94(44.0)$ \\
$\begin{array}{l}\text { In pathology introductory course, you remembered practical } \\
\text { histology well and this helped you in practical pathology. }\end{array}$ & $85(39.7)$ & $52(24.3)$ & $77(36.0)$ \\
$\begin{array}{l}\text { In the pathology lab sessions in introductory course, the ratio of } \\
\text { slides that you remembered their normal tissue counterparts was } \\
\text { more than 50\%. }\end{array}$ & $90(42.1)$ & $57(26.6)$ & $67(31.3)$ \\
$\begin{array}{l}\text { Practical histology needs more lab sessions and more effort by } \\
\text { instructors than what you took. }\end{array}$ & $110(51.4)$ & $53(24.8)$ & $51(23.8)$ \\
\end{tabular}

Table III. Participants' perceptions of different methods for improving the teaching of microscopic morphology.

\begin{tabular}{lccc}
\hline Questionnaire element & $\begin{array}{c}\text { Strongly } \\
\text { disagree/Disagree } \\
(\%)\end{array}$ & $\begin{array}{c}\text { Neutral } \\
(\%)\end{array}$ & $\begin{array}{c}\text { Strongly } \\
\text { Agree/Agree } \\
(\%)\end{array}$ \\
\hline $\begin{array}{l}\text { Courses integrating histology and pathology in the first and } \\
\text { second years are better than teaching each discipline alone. }\end{array}$ & $51(23.8)$ & $3(15.4)$ & $130(60.7)$ \\
$\begin{array}{l}\text { It is better to add case discussions combining histology and } \\
\text { pathology. }\end{array}$ & $33(15.4)$ & $3(15.4)$ & $148(69.2)$ \\
$\begin{array}{l}\text { Microscope is more effective than images in teaching } \\
\text { pathology microscopic morphology. }\end{array}$ & $58(27.1)$ & $0(28.0)$ & $96(44.9)$ \\
$\begin{array}{l}\text { It is more effective to draw microscopic images in histology. } \\
\text { It is better to see normal and abnormal examples of the same } \\
\text { tissue type at the same time. }\end{array}$ & $58(27.1)$ & $2(29.0)$ & $94(43.9)$ \\
$\begin{array}{l}\text { In teaching histology and pathology, System approach is } \\
\text { more effective than each discipline alone. }\end{array}$ & $7(3.3)$ & $20(9.3)$ & $187(87.4)$ \\
$\begin{array}{l}\text { It is better for histology lab material in the first year to be } \\
\text { restricted to what need to be compared with common } \\
\text { pathologic conditions. }\end{array}$ & $16(7.5)$ & $7(22.0)$ & $151(70.6)$ \\
\hline
\end{tabular}

teaching each discipline alone (Table III). The number of respondents who agreed or strongly agreed with merging histology and pathology in the first year curriculum was significantly associated with the number of those who were with restricting first year histology examples to only what is needed for the pathologic entities ( $\mathrm{p}$ value $=0.001$ ) 


\section{DISCUSSION}

Since histology and pathology are of the basic medical disciplines that are image-intensive, several methods were used to enhance students' understanding and knowledge retention. At our institution, students complete general histology and introduction to pathology courses by the end of first year second semester and second year first semester, respectively. The second-year pathology course is essential for providing medical students with the knowledge they need on core principles of disease processes. In our study, a large number of students found pathology interesting $(72.9 \%)$. This was higher than the number reported in a recent study from Malaysia (55.4\%) and another one from India (64.8\%) (Shah, et al., 2014; Emerald et al., 2016). However, there were only $15.4 \%$ of the participants in our study considered pathology among their career choices. This attitude toward pathology targeted several studies to address medical students' perceptions of this specialty (Haspel et al.). The role of the second year pathology course without educating medical students about pathology practice and continuing into the clinical years was reported to have a little effect on students' attitudes toward pathology (Holland \& Bosch). In addition, pathologists input in preclinical years curricula is necessary (Gray \& El-Kadiki, 2010). There were $60.7 \%$ of participants who agreed or strongly agreed with the proposed integration of histology and pathology. Moreover, system approach in teaching pathology with other disciplines was preferred by $70.6 \%$, and was comparable to several studies (Shah, et al.; Emerald et al.). Integrated curricula in teaching laboratory medicine has shown to be effective in medical students satisfaction and better understanding (Osman et al., 2013, 2014). The need to start the integration of histology and pathology in the first year is well highlighted by the ratio of students who were unsatisfied with practical histology of first year $(60.3 \%)$, along with the significant proportion of students who were with co-presenting normal and abnormal examples at the same time in the second year pathology introduction $(87.4 \%)$. Correlating normal histology of organs with morphology of disease is a major learning outcome that boosts students' knowledge and understanding (Amin et al., 2016). In addition, combining this integration with new teaching and learning methods such as virtual microscopy needs to be tested (Kumar et al., 2006). However, our results showed that microscopy is still a preferred tool for $44.9 \%$ of students.

\section{CONCLUSIONS}

Our experience showed that the curricular integration of histology and pathology in the first year needs to be tested.
In addition, case discussions proved to be successful, and microscope remains an effective and preferred tool for teaching microscopic morphology. However, much effort is needed to increase students' affinity for anatomic pathology.

\section{AL KHADER, A.; OBEIDAT, F. N.; ABU SHAHIN, N.; KHOURI, N. A.; KADDUMI, E. G.; AL QA'QA', S.; AL- SHATANAWI, T. N.; JABER, H.; AL-SAGHBINI, M. \& AMER, N. Percepciones de los estudiantes de medicina sobre Patología y una propuesta de integración curricular con Histología: Una vi- sión futura de cambio curricular. Int. J. Morphol., 38(1):38-42, 2020.}

RESUMEN: Las percepciones y comentarios de los estudiantes tienen un impacto significativo en el progreso académico. El objetivo de este estudio fue determinar las percepciones de los estudiantes de medicina con respecto a los efectos acumulativos del curso de Histología general de primer año y del curso introductorio de Patología de segundo año, además de sus percepciones con respecto a la integración curricular de Histología y Patología. En este estudio transversal, se entregó un cuestionario a estudiantes de medicina de segundo y tercer año, a mediados del segundo semestre. Asimismo, el cuestionario comprendió varios aspectos referente a la actitud de los estudiantes hacia Patología Anatómica, sus comentarios sobre la Histología general en el primer año y los cursos de Patología de segundo año. Además se incorporaron las percepciones de los estudiantes con respecto a la integración de los cursos de Histología y Patología. Se utilizó una escala de Likert de cinco puntos. Los datos se analizaron utilizando el paquete Statistical Package for Social Science (SPSS) v 20. Se analizaron 214 de los 236 cuestionarios distribuidos (tasa de respuesta $=90,7 \%$ ). Más del $51 \%$ de los encuestados indicaron estar de acuerdo o totalmente de acuerdo, en que no lograron identificar el tejido normal, en la mayoría de los casos de Patología práctica. Solo el 31,3\% observó que su conocimiento de Histología práctica era beneficioso para ellos durante la Patología práctica. Más del 87 \% estuvo de acuerdo o muy de acuerdo en que los casos de Patología deben ser analizados con muestras de tejido normal. Un grupo importante de los encuestados (60,7 \%) consideraba incorporar la Histología y la Patología en cursos integrados. Patología fue de elección en la carrera para el 15,4 \% de los participantes. La integración curricular de Histología y Patología en el primer año, debe ser evaluada con el propósito de incrementar la afinidad de los estudiantes con la Patología Anatómica.

PALABRAS CLAVE: Patología; Histología; Estudiantes de medicina.

\section{REFERENCES}

Amin, N. F.; Yesmin, Z. A. \& Akter, M. Effective cell biology and histology teaching for medical undergraduates in Bangladesh: A review. Ann. Int. Med. Dent. Res., 2(1):3-8, 2015. 
Atukorala, K. \& Atapattu, P. M. Pre clinical- basic sciences teaching curriculum of a medical school in a developing country-Are we doing it right? J. Bangladesh Soc. Physiol., 9(2):98-104, 2015.

Beck, A.; Wood, C.; Helms, R.; Arvizo, C.; Cherry, B. M. \& Ziats, N. P. Peerassisted learning in introductory histopathology improves learner scores and delivers learner satisfaction. Med. Sci. Educ., 26(1):85-92, 2016.

Campos-Sánchez, A.; López-Núñez, J. A.; Scionti, G.; Garzón, I.; GonzálezAndrades, M.; Alaminos, M. \& Sola, T. Developing an audiovisual notebook as a self-learning tool in histology: perceptions of teachers and students. Anat. Sci. Educ., 7(3):209-18, 2014.

Cogdell, B.; Torsney, B.; Stewart, K. \& Smith, R. A. Technological and traditional drawing approaches encourage active engagement in histology classes for science undergraduates. Biosci. Educ., 19(1):1$15,2012$.

Colgan, T. J. \& Geldenhuys, L. The practice of pathology in Canada: decreasing pathologist supply and uncertain outcomes. Arch. Pathol. Lab. Med., 136(1):90-4, 2012.

Emerald, N. M.; Han, T. Z. \& Oo, S. S. Students' perception on effectiveness of pathology teaching in phase 1 medical program at UCSI University. Int. J. Med. Sci. Educ., 3(3):264-73, 2016.

Ghanchi, N. K.; Nizamuddin, R. N.; Qasim, A.; Khaled, Z. N.; Raheem, A. B.; Ali, N.; Kayani, N. \& Beg, M. A. Perception of pathology as a future career choice among medical Students from Karachi, Pakistan: Experience from a private medical school. J. Pak. Med. Assoc., 67(4):627-9, 2017.

Gray, T. A. \& El-Kadiki, A. Filling the gaps in undergraduate teaching of clinical biochemistry. J. Clin. Pathol., 63(2):99-101, 2010.

Haspel, R. L.; Bhargava, P.; Gilmore, H.; Kane, S.; Powers, A.; Sepehr, A.; Weinstein, A. R.; Schwartzstein, R. M. \& Roberts, D. H. Successful implementation of a longitudinal, integrated pathology curriculum during the third year of medical school. Arch. Pathol. Lab. Med., 136(11):1430-6, 2012.

Herrmann, F. E.; Lenski, M.; Steffen, J.; Kailuweit, M.; Nikolaus, M.; Koteeswaran, R.; Sailer, A.; Hanszke, A.; Wintergerst, M.; Dittmer, S.; et al. A survey study on student preferences regarding pathology teaching in Germany: a call for curricular modernization. B. M. C. Med. Educ., 15:94, 2015.

Hightower, J. A.; Boockfor, F. R.; Blake, C. A. \& Millette, C. F. The standard medical microscopic anatomy course: histology circa 1998. Anat. Rec., 257(3):96-101, 1999.

Holland, L. \& Bosch, B. Medical students' perceptions of pathology and the effect of the second-year pathology course. Hum. Pathol., 37(1):18,2006 ?

Hortsch, M. Using Virtual Microscopy-Advancing Anatomical Education Worldwide. FASEB J., 31(1 Suppl.):89.1, 2017.

Hung, T.; Jarvis-Selinger, S. \& Ford, J. C. Residency choices by graduating medical students: why not pathology? Hum. Pathol., 42(6):802-7, 2011.

Kumar, R. K.; Freeman, B.; Velan, G. M. \& De Permentier, P. J. Integrating histology and histopathology teaching in practical classes using virtual slides. Anat. Rec. B New Anat., 289(4):128-33, 2006.

Lisk, K.; Agur, A. M. \& Woods, N. N. Exploring cognitive integration of basic science and its effect on diagnostic reasoning in novices. Perspect. Med. Educ., 5(3):147-53, 2016.

Malau-Aduli, B. S.; Lee, A. Y.; Cooling, N.; Catchpole, M.; Jose, M. \& Turner, R. Retention of knowledge and perceived relevance of basic sciences in an integrated case-based learning (CBL) curriculum. B. M. C. Med. Educ., 13:139, 2013.

Moxham, B. J.; Emmanouil-Nikoloussi, E.; Brenner, E.; Plaisant, O.; Brichova, H.; Kucera, T.; Pais, D.; Stabile, I.; Borg, J.; Scholz, M.; et $a l$. The attitudes of medical students in Europe toward the clinical importance of histology. Clin. Anat., 30(5):635-43, 2017.

Osman, M. T.; Adnan, A.; Kutty, M. K. \& Al-Naggar, R. A. Evaluation of laboratory medicine teaching and learning by medical students in hybrid integrated curriculum. Data from public Malaysian University. J. Basic Appl. Sci. Res., 4:151-7, 2014.

Osman, M. T.; Kutty, M. K.; Adnan, A.; Al-Naggar, R. A.; Bakar, N. S.;
Omar, E.; Kornain, N. K. M. \& Rahman, S. A. Perceptions of year one Malaysian medical students towards teaching and learning of general pathology in hybrid integrated curriculum. World Appl. Sci. J., 23(7):977-82, 2013.

Rafi, A.; Rauf, A. \& Anwar, M. I. Significance of actually drawing microscopic images and its impact on students' understanding of histology. J. Dow Univ. Health Sci. Karachi, 11(3):77-81, 2017.

Shah, A. R.; Shethwala, N. D. \& Parmar, B. H. Perception of undergraduate medical students towards the subject of Pathology at one of the Medical Colleges of Gujarat, India. Int. J. Med. Sci. Public. Health, 3(7):863-5, 2014.

Shaw, P. A. \& Friedman, E. S. Clinico-histologic conferences: histology and disease. Anat. Sci. Educ., 5(1):55-61, 2012.

Singh, A. Student performance and their perception of a patient-oriented problem-solving approach with audiovisual aids in teaching pathology: a comparison with traditional lectures. Adv. Med. Educ. Pract., 2:9-15, 2011.

\author{
Corresponding author: \\ Ali Al Khader \\ Department of Basic Medical Sciences \\ Faculty of Medicine \\ Al-Balqa Applied University \\ Al-Salt \\ JORDAN
}

Email: ali.alkhader@bau.edu.jo

Received: 10-06-2019

Accepted: 17-07-2019 